American Journal of Environmental Sciences 8 (3): 202-211, 2012

ISSN 1553-345X

(C) 2012 Science Publications

\title{
Ecological Monitoring of Danube water Quality in Budapest Region
}

\author{
Hosam E.A.F. Bayoumi Hamuda and Istvan Patko \\ Environmental Protection Engineering Institute, \\ Rejto Sandor Faculty of Light Industry and Environmental Protection Engineering, \\ Obuda University, Budapest, Hungary
}

\begin{abstract}
Problem statement: Serious health problems and other economic costs related to water treatment, remediation and locating a new water supply, become an evidence of water pollution caused by human activities. The main problems of the Danube River basin are associated with nutrients, organic pollution and hazardous pollutants. The aim of the study is to assess the surface water of the Danube in Budapest for sustainability of human and environment health. Approach: The monitoring assessment of comparative studies was carried out in June of 1998, 2005 and 2010 using the Hungarian standard methods. The samples were collected in sterile dark bottles from three different zones in Budapest. Results: The results demonstrated that dissolved organic carbon content, nutrient pollution (total $\mathrm{N}$ and $\mathrm{P}$ ), bacteriological parameters and chlorophyll-a content were higher in 2005 than in 1998 and 2010. The results indicated that the bacteriological assessments and bacterial populations were low in 1998 in comparison with the results of 2010. In 2005, investigations illustrate the high fecal pollution. The data showed no significant differences between temperature, $\mathrm{pH}$ and Electrical conductivity in 1998, 2005 and 2010. Conclusion/Recommendations: Monitoring of the water by physicochemical and bacteriological is essential to identify the aquatic ecosystem hazards. The relation between $\mathrm{O}_{2}$ and Chl-a content of the samples, clearly shows that the cause of high dissolved $\mathrm{O}_{2}$ content in the water lies in accelerated primary production. Enumerations of both total and fecal Coliforms are continuously growing during the investigation periods. These results suggested that bacteriological properties can be a specific indicator of fecal contamination and organic pollution. With large numbers of new chemical substances entering the river ecosystem, continuous monitoring systems for their detection will become increasingly important with respect to environmental effects they produce, in addition to other toxic effects. The challenges to continuous physical, chemical, biological and bacteriological monitoring will be immense.
\end{abstract}

Key words: Ecological monitoring, pollution, danube river water quality, physicochemical parameters

\section{INTRODUCTION}

The quality of human life is strongly related to a clean environment. The urbanization, industrialization and agriculture have led to the deterioration in water quality due to various contaminants. River is a dynamic ecosystem and the problems of water quality are closely related to pollution, eutrophication (hypertrophication), dysfunction and acidification which lowering the standard level of water. Water quality monitoring of international rivers has always been a difficult task. The Danube River is the second longest river in Europe with a total length of about $2800 \mathrm{~km}$. Its catchment area covers $801500 \mathrm{~km}^{2}$, with approximately 81 million inhabitants in 19 countries. The Danube itself is shared by nine riparian countries and five capitals with 0.5 to 2.5 million inhabitants contributing to the extensive water use and pollution. Drinking water production from river bank filtrates and the supply of water for domestic, agricultural and industrial use are of major importance in all of these countries. The Danube River (Fig. 1) is the only European river flow from West (Black Forest Mountains, Germany) to East (Black Sea, Bulgaia).

The main problems affect water quality of the river are high nutrient load, contamination with hazardous substances and $\mathrm{O}_{2}$ depletion. Today, it is important to improve the water quality of the river ecosystem to meet the demand from different sectors and to improve the capacity of water supply for domestic, agriculture, industry, energy and other uses.

Corresponding Author: Hosam E.A.F. Bayoumi Hamuda, Environmental Protection Engineering Institute, Faculty of Light Industry and Environmental Protection Engineering, Obuda University, Budapest, Hungary 


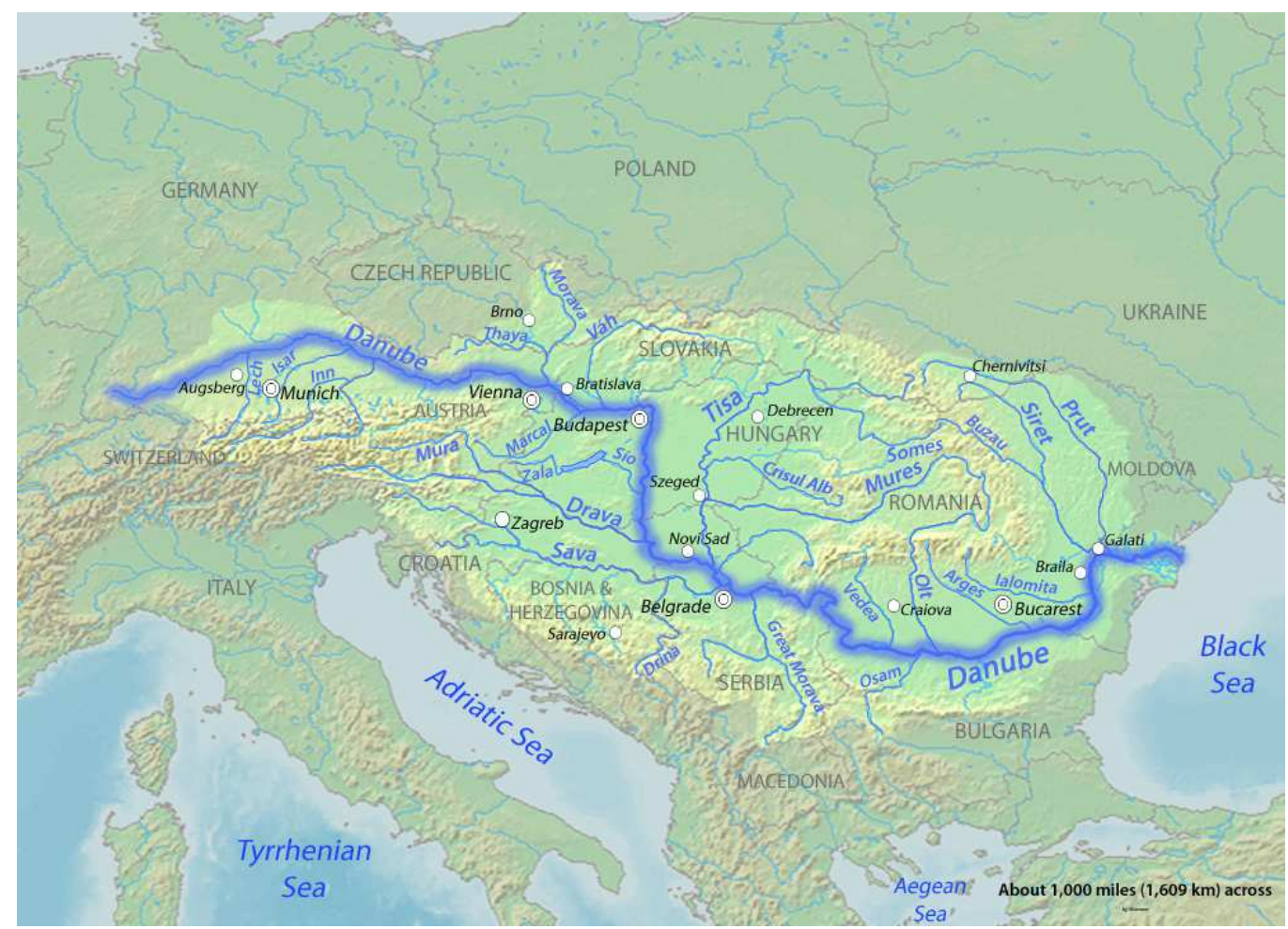

Fig. 1: Flow of Danube River

Budapest is found in downstream on the Danube River passes through the Hungarian Lowlands and the water quality often decreased to class II-III, indicating significant organic pollution. After more than four decades of development there are a number of reliable chemical monitoring systems for river, but biological monitoring is still in the stages of infancy (Jeon et al., 2008). Chemical monitoring was introduced in most of the large rivers of Europe with varying amount of sophistication. Monitoring the biological quality of rivers has a long tradition in the Danube River Basin. Several countries supported research on bioassessment and monitoring (Sladecek, 1973).

Microbiological contamination is an important water quality problem in the World. The discharge of organic matter is considered to be a crucial problem throughout the Danube River basin has negative impacts on hydrology of the Danube and makes the water unhealthy to use. Isobe et al. (2004) investigated the relationship between concentrations of bacterial and a chemical indicators in tropical and temperate regions. In Tokyo, higher bacterial densities were usually observed during summer. Taking into account the high chlorophyll-a (Chl-a) values as well as the extreme over-saturation with $\mathrm{O}_{2}$, secondary pollution caused by an elevated phytoplankton biomass was recognizable.
Bacteriological contamination from fecal pollution from anthropogenic activities is considered to be a crucial problem throughout the Danube River basin. Thus, detailed knowledge of the extent and the origin of microbial pollution is essential for watershed management. The determination of fecal indicator concentrations along the Danube and its major tributaries during two whole-river surveys and 16 permanent stations allowed for the first time to draw a clear picture of the fecal pollution patterns along the whole longitudinal profile of this important international river (Kirschner et al., 2009). The results suggested that Escherichia coli is a specific indicator of fecal contamination in both tropical and temperate regions but that the densities are affected by elevated water temperature and input from runoff of soil particles. The concurrent determination of E. cole concentrations could provide a possible approach to assessing the reliability of fecal pollution monitoring data. Khadse et al. (2011) mentioned that to ascertain the quality of drinking water being supplied, water quality monitoring and surveillance was conducted at various treatment stages, service reservoirs, distribution network, public stand posts and households. No significant change in raw water quality was observed on day-to-day basis. Residual $\mathrm{Cl}^{-}$was found in the range 
of 0 to $0.2 \mathrm{mg} \mathrm{L}^{-1}$ in the sump water/finished water. Throughout the year, the total and faecal coliform counts were ranged from 0 to $7 \mathrm{CFU} / 100 \mathrm{ml}$ and 0 to 3 CFU/100 mL, respectively. Evaluation of the raw water quality indicates that the water is suitable for drinking after conventional treatment followed by disinfection. They concluded that water supplied through the distribution network is of good physicochemical and bacterial quality in general. The objectives of this study were to investigate physical, chemical, biological and bacteriological status for water quality of the Danube River in Budapest city during various time intervals.

\section{MATERIALS AND METHODS}

To make sure that the investigated water samples of Danube River in Budapest region were representative, they were taken from the right (Pest) and the left (Buda) sides of the river's bank at every sampling station. The water samples were collected in June of 1998, 2005 and 2010 from six sites of three different zones between the Erzsébet and Petőfi bridges with three replicates. All samples for physical, chemicals, biological and bacteriological analysis were collected in ( one litre capacity) sterile dark bottles without air bubbles and immediately placed on dark cooling boxes and processed within six hours of collection.

According to Hungarian national standard methods, the following methods were used to assess the ecological monitoring of Danube surface water quality in Budapest: pH: MSZ 448-22-1985, temperature: MSZ EN 27888:1998, electrical conductivity: MSZ 448-321977, $\mathrm{NH}_{4}^{+}$: MSZ ISO 7150-1-1992, $\mathrm{Na}^{+}$and $\mathrm{K}^{+}$: MSZ 448-10-1977, $\mathrm{Ca}^{2+}$ and $\mathrm{Mg}^{2+}$ : MSZ 448-3-1985, $\mathrm{Cl}^{-}$: MSZ EN ISO 10304-1-1998, $\mathrm{NO}_{3}^{-}$: MSZ 448-12-1982, $\mathrm{NO}_{2}{ }^{-}$: MSZ 448-12-1982, ortho- $\mathrm{PO}_{4}{ }^{3-}$ : MSZ 448-181977, $\mathrm{CO}_{3}{ }^{2-}$ : MSZ 448-21-1986, $\mathrm{SO}_{4}{ }^{2-}$ : MSZ 1275016-1988, total P: MSZ 448-18-1977, total N: MSZ 44827-1985, total organic carbon content (TOC): MSZ EN 1484-1998, suspended solids: MSZ EN ISO 7827-1998, dissolved $\mathrm{O}_{2}$ : MSZ EN 25814-1998, COD: MSZ ISO 6060-1991, BOD: MSZ ISO 5815-1998, Fe: MSZ 12750- 34-1986, Mn: MSZ 1484- 2-1993, Ni, Cu, Zn and Pb: MSZ EN ISO 5961:1998. Content of chlorophyll-a: MSZ ISO 10260-1993, total and faecal coliform bacteria: MSZ ISO 9308-2-1994. Detection of Escherichia coli: Faecal streptococcus: MSZ 448-441990 and, Enterococcus faecalis: MSZ 12749-1993. Total aerobic heterotrophic bacteria were enumerated by standard plate count by serial dilution of the sample, followed by the conventional spread plate method (Chen and Kueh, 1976) and the colony count were measured after incubation at $37^{\circ} \mathrm{C}$ for $24 \mathrm{~h}$. Cellulose- decomposers were determined according to Hendricks et al. (1995). The populations of bacteria were expressed in terms of $\log _{10}$.

\section{RESULTS}

Water could be chemically, physically or bacteriologically polluted. Each of which is linked to various sources and health related problems and consequences. The major factors determine the chemical and bacteriological consist of water quality: artificial and natural polluttion. Any chemical or bacteriological analysis of water reveals the joint impacts of both sources of polluttion and it is difficult to fully identify and separate these sources. Monitoring assessments for the surface water quality of Dunabe River in Budapest region are presented in the following 11 figures. The results present in the following figures are in the avarege of three replicates of six investigated sites on both sides of the river basin.

Figure 2 illustrates the variations in $\mathrm{pH}$ and electrical conductivity measurements of Danube water. It was found that the highest values of $\mathrm{pH}$ and eclectrical conductivity were measured in 2005. Also, it shows significant differences between the $\mathrm{pH}$ values in 2005 and 2010, but not between the $\mathrm{pH}$ values in 1998 and 2005. The results showed no significant differences between the electrical conductivities values in 1998 and 2010, but it was significant between 1998 and 2005 as well as between 2005 and 2010. Figure 3 represents the comparative monitoring measurements of temperature and dissolved $\mathrm{O}_{2}$. Results indicated no significant differences between the temperature variations in 1998 and 2010 and significant between 2005 and 2010. The highest temperature was measured 2005 and the lowest was in 2010. The lowest dissolved $\mathrm{O}_{2}$ measurements were recorded in 1998, while the highest values of dissolved $\mathrm{O}_{2}$ were recorded in 2005. Maximum $\mathrm{Ca}^{2+}$ ion concentrations were measured in 2010. Also, the maximum values of $\mathrm{Mg}^{2+}, \mathrm{Na}^{+}, \mathrm{K}^{+}$and $\mathrm{NH}_{4}{ }^{+}$ions were measured in 1998 and the lowest concentrations were in 2010 (Fig. 4). Generally, the ion concentration decreasing order was $\mathrm{Ca}^{2+}>\mathrm{Mg}^{2+}>\mathrm{Na}^{+}>\mathrm{K}^{+}$and $\mathrm{NH}_{4}{ }^{+}$. Figure 5 shows the the variations in the anion ions concentrations in the surface water samples of Danube River region located in Budapest. The results illustrated that ion concentrations of $\mathrm{CO}_{3}{ }^{2-}$ and $\mathrm{SO}_{4}{ }^{2-}$ were highest in 2010 and lowest in 1998, $\mathrm{Cl}^{-}$and O$\mathrm{PO}_{4}{ }^{3-}$ were maximum in the water samples in 1998 and minimum in 2010. It was found that the highest and lowest concentrations of $\mathrm{NO}_{3}{ }^{-}$and $\mathrm{NO}_{2}{ }^{-}$ions were measured in 2005 and 2010, respectively. 
Am. J. Environ. Sci., 8 (3): 202-211, 2012

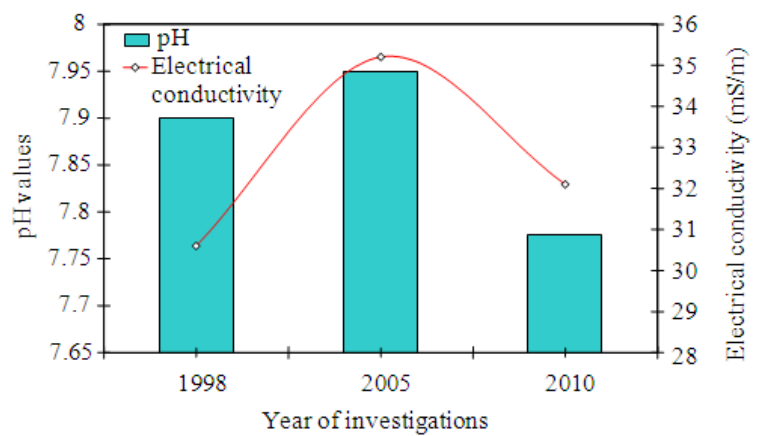

Fig. 2: Changes in $\mathrm{pH}$ values and electrical conductivity

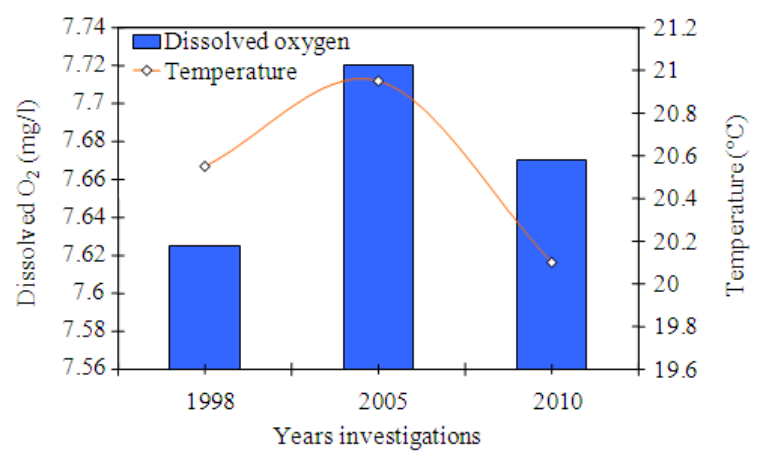

Fig. 3: Variations in dissolved oxygen and temperature

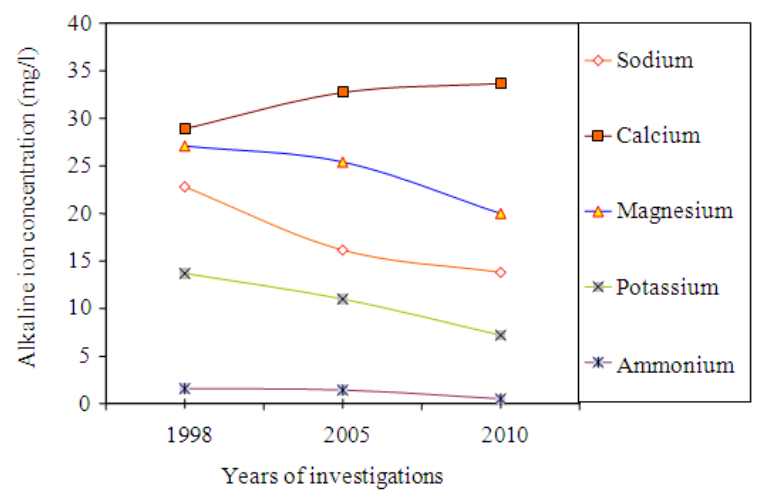

Fig. 4: Measurements of alkaline ions concentrations

Figure 6 illustrates the total $\mathrm{N}$ and $\mathrm{P}$ contents in the tested water samples. Results showed the highest values of total $\mathrm{N}$ and $\mathrm{P}$ were in 2005. The results showed that the total $\mathrm{N}$ contents were highly reduced in 2010 and lowest total P values were measured in 1998. Figure 7 demonstrates the ion concentrations of $\mathrm{Mn}$ and Fe. The lowest concentrations of these two cations were recorded in 2010. Maximum ions concentrations of $\mathrm{Mn}$ and $\mathrm{Fe}$ were measured in 1998 and 2005, respectively.

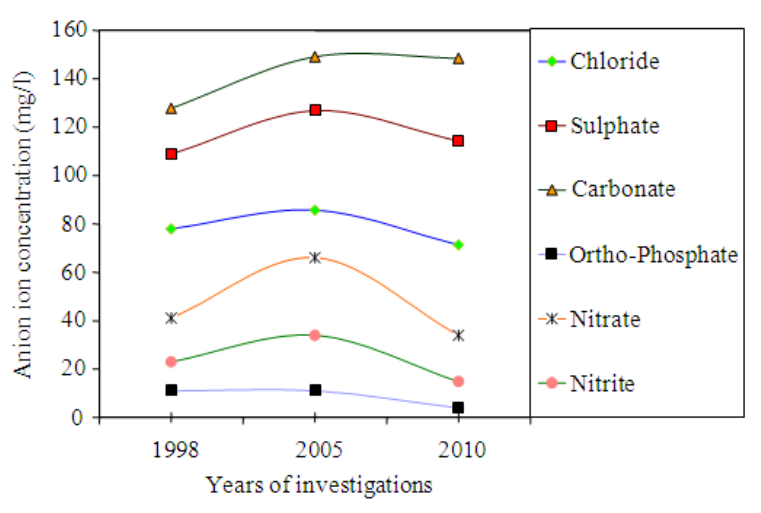

Fig. 5: Variations in anion ions concentrations

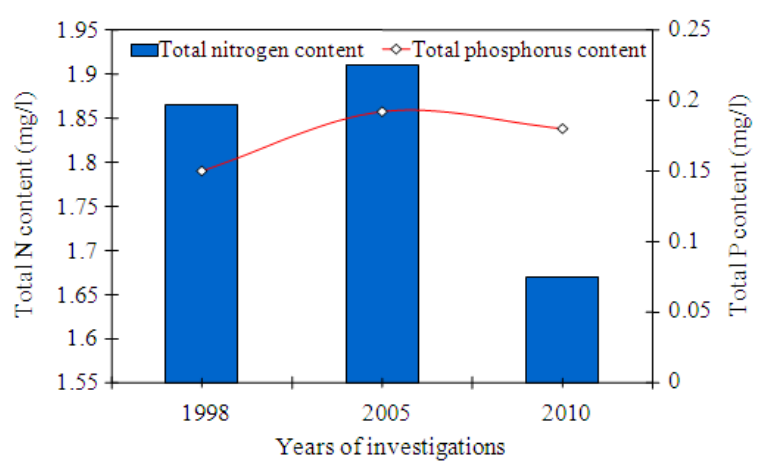

Fig. 6: Total nitrogen and phosphorus contents in river

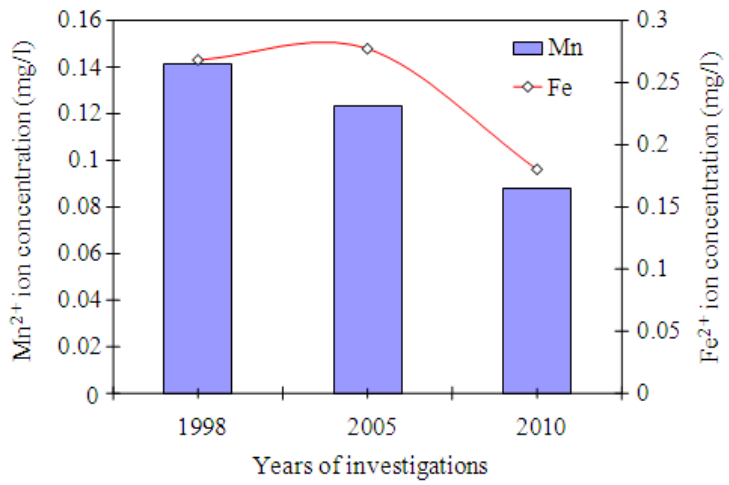

Fig. 7: Ion concentrations of manganese and iron

The results indicated that there were gradually reduction in the ion concentrations of measured heavy metals in the surface water samples from 1998 to reach the minimum levels in 2010 (Fig. 8). 


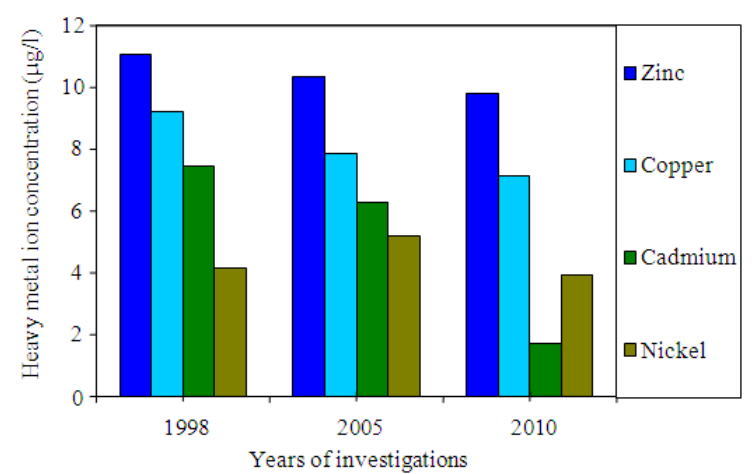

Fig. 8: Vules of heavy metal ion concentration in river

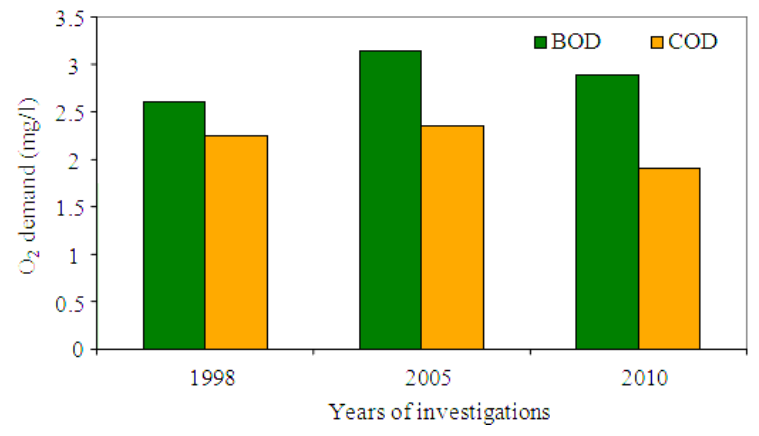

Fig. 9: Biological and chemical oxygen demand in Danube River in Budapest region

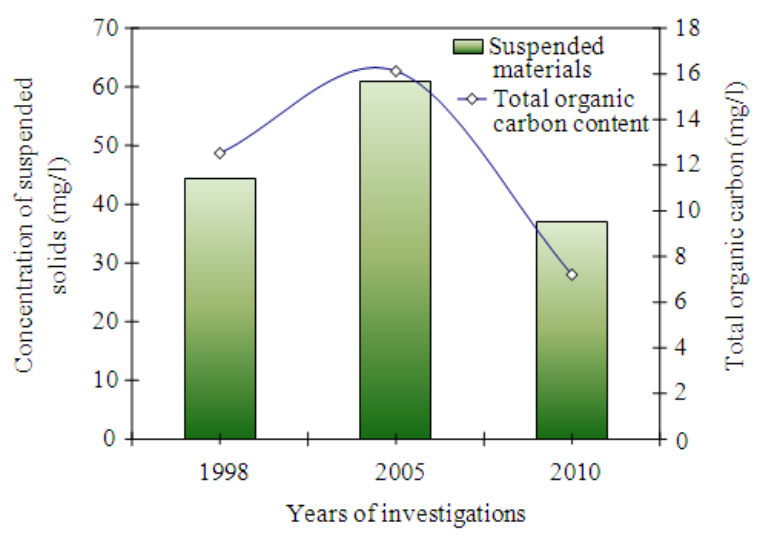

Fig. 10: Concentrations of suspended solids and total organic carbon in water river

Among heavy metals, the highest ion concentrations were recorded by $\mathrm{Zn}$ followed by $\mathrm{Cu}, \mathrm{Ni}$ and $\mathrm{Cd}$. The measurements of BOD and COD were not show significant differences among the recorded data in 1998, 2005 and 2010. Maximum values of BOD and COD were measured in 2005. The lowest values of BOD were recorded in 1998 and for COD were in 2010 (Fig. 9).

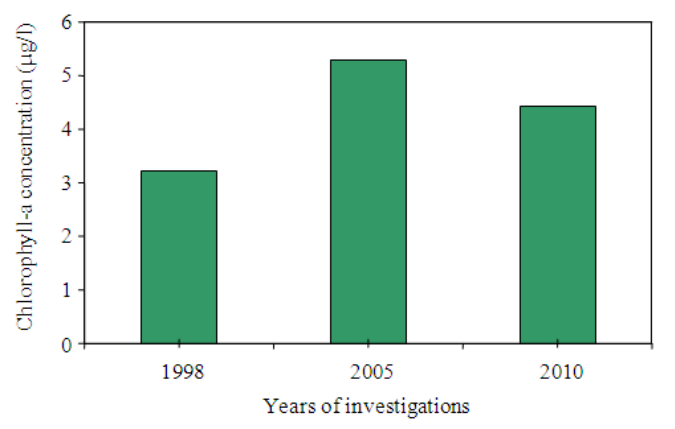

Fig. 11: Chlorophyll-a content of Danube in Budapest

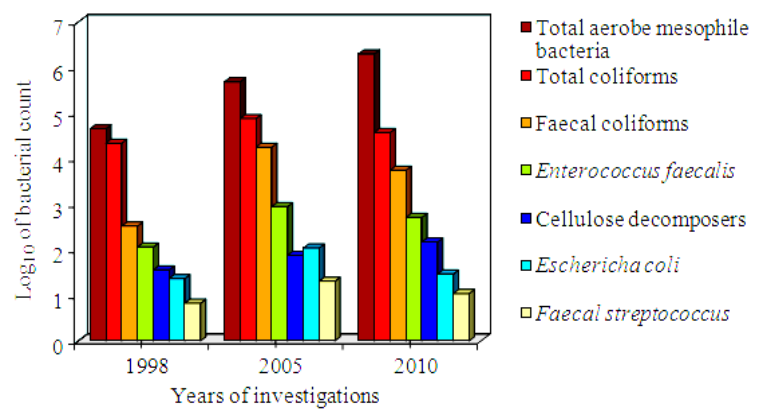

Fig. 12: Comparison of bacteriological properties of surface water in Danube

Figure 10 shows the concentration values of suspended solid materials and TOC. It was found that the lowest amounts of suspended solid materials and TOC were 2010 and the highest values were recordrd in 2005. The data illustrated positive correlations between the amounts of suspended solid materials and TOC content throughout the investigated time intervals.

The content of Chl-a of planktonic organisms acts as an indicator for eutrophication. Figure 11 shows one of the biological indicators is the contents of Chl-a in Danube surface water quality. The monitoring method showed that the Chl-a was lowered in 2010 than 2005 and the lowest measurements were in 1998. Following evaluation of organic pollution and eutrophication in addition to the above-mentioned water status of the surface water quality of Danube River, bacteriological parameters (total and faecal coliforms, faecal streptococci, heterotrophic bacteria and cellulose decomposers) were analyzed in the study area of Danube water. In this study, the enumeration of total counts of aerobe heterotroph mesophile bacteria, total and faecal coliforms, faecal streptococci, E. coli, E. faecalis and cellulose-decomposers of surface water samples collected from the Danube River in Budapest region are illustrated in Fig. 12. 
The bacteriological assessments expressed in the term of $\log _{10}$ of the colony formed units showed that the total counts of aerobic heterotroph mesophile bacteria and the total cellulose-decomposers were gradually increased from 1998 to 2005 and reach the maximum in 2010. Coliform bacteria have long been used to indicate faecal contamination of water and thus a health hazard.

One-way analysis of variance demonstrated the significant differences in total counts of aerobe heterotroph mesophile bacteria, total and faecal coliforms, faecal streptococci, E. coli, E. faecalis and cellulose-decomposers densities between the surveys at p < 0.05. The highest $\log _{10}$ value of E. coli per $100 \mathrm{ml}$ was found during 2005 season (2.04), followed by the 2010 (1.47) season and 1998 (1.37). The results showed that in 2010, the population densities of aerobe heterotrophy mesophile bacteria, total counts and faecal coliforms, faecal streptococci, E. faecalis and cellulose decomposers had similar order of magnitudes to $E$. coli as in 1998.

The measured bacteriological indicator parameters provided a consistent picture of faecal pollution in the Danube River in Budapest region throughout the three investigation peroids. The third measurement in 2010, showed an increase of population of E. coli as a faecal indicator at the capital of Hungary occurred was higher than the levels measured in 2005 and lowest population was found in 1998. Highest enterococci population was observed in 2005, followed by 2010 and 1998. Total coliforms also showed by highest contamination levels in 2005 and the populations differences between the contamination in 1998 and 2010 was very low. Faecal indicators were all highly significantly intercorrelated in three investigated peroids.

The ratio between $E$. coli and enterococci varied between 0.545 (1998), 0.692 (2005) and nearly similar to 0.543 (2010). The results indicated that the bacteriological assessments and bacterial populations were low in 1998 in comparison with the results of 2010. In 2005, investigations illusterated the high faecal pollution.

\section{DISCUSSION}

Most of cities located on the banks of the river use raw water from the river for drinking water supply and discharge the untreated/treated municipal sewage into it. Water acts as a media for both chemical and biochemical reactions and also as internal and external medium for several organisms. Rapid population growth and urbanization have been accompanied by high health risks due to increasing inputs of untreated domestic wastewater to rivers.
Monitoring the physicochemical, biological and bacteriological quality of rivers has a long tradition in the Danube River Basin. For the implementation of the European Water Framework Directive class boundaries of biological assessment methods need to be intercalibrated. The common applied intercalibration approach of national river assessment methods in Europe requires data on near-natural reference sites; however, these data are generally scarce (Birk and Hering, 2009).

Water quality is one of the main issues in the water sector in all over the World and its improvement is a major concern. Bacterial pollution of water continues to be a widespread problem across the World and is a major cause of illness and deaths by water-borne diseases. The monitoring results obtained during 2005 indicate that organic pollution continues to be predominant in surface water of Danube River. High concentrations of biomass/Chl-a were found in the Danube downstream of Budapest, which indicates elevated eutrophication in this reach of the Danube River. The over production of biomass can lead to a variety of problems ranging from anoxic waters to toxic algal blooms, a decrease in biodiversity and habitat destruction.

The slight alkaline $\mathrm{pH}$ values and dissolved $\mathrm{O}_{2}$ levels in the Danube water varied in accordance with the increased primary productivity and degradation of the organic pollution. The algal blooming observed during the survey increased both the $\mathrm{pH}$ values and the dissolved $\mathrm{O}_{2}$ concentration.

Organic pollution measured in terms of BOD and coliform bacterial counts gives an indication of the extent of water quality degradation in different parts of the country. A critical evaluation of data presented indicated that different forms of $\mathrm{N}$ and $\mathrm{P}$ were measured in water samples. Both O- $\mathrm{PO}_{4}{ }^{3-}$ and total-P showed a slight increase in the surface water samples.

No significant change in raw water quality was observed on day-to-day basis. Residual $\mathrm{Cl}^{-}$was found in the range of 0 to $0.2 \mathrm{mg} \mathrm{L}^{-1}$ in the sump water/finished water. Throughout the year (i.e., during summer, winter and monsoon seasons), the total and faecal coliform bacterial counts were ranged from 0 to $7 \mathrm{CFU} / 100 \mathrm{~mL}$ and 0 to $3 \mathrm{CFU} / 100 \mathrm{~mL}$, respectively, in sump water of Sleep and VIP complex water treatment plant; however, at consumer end, those were observed as 0 to $210 \mathrm{CFU} / 100 \mathrm{~mL}$ and 0 to 90 CFU/100 mL, respectively.

All faecal pollution parameters showed a consistent correlation pattern with the concomitantly measured environmental variables. Significant correlation was found with Chl-a, bacterial production, particulate 
dissolved organic $\mathrm{C}$ content and suspended solid materials. All other variables (water temperature, $\mathrm{pH}$, $\mathrm{NO}_{3}{ }^{-}, \mathrm{NH}_{4}^{+}$, total $\mathrm{N}, \mathrm{P}$, electrical conductivity, suspended solid materials and DOC) showed no significant correlation with faecal indicators. Bacterial numbers positively correlated with enterococci and total coliforms, which were as well negatively correlated with $\mathrm{PO}_{4}{ }^{3-}$. Significant correlations of faecal indicators were observed for the whole data set including Chl-a, total $\mathrm{P}$ and total suspended solid materials. A high ratio of E. coli to faecal streptococci suggests a human source and a ratio less than one suggests an animal source. A differential count of the actual streptococcal species present in water can help to find out the exact source of contamination. These variations in bacterial counts among the different service reservoirs and consumer ends may be attributed to the general management practices for maintenance of service reservoirs and the possibility of enroute water pollution.

Evaluation of the raw water quality indicates that the water is suitable for drinking after conventional treatment followed by disinfection. The finished water quality meets the level of standards described by Bureau of Indian Standard specifications for portability in terms of its physicochemical characteristics (Khadse et al., 2011). Ahmad and Qadir (2011) mentioned that the physicochemical parameters such as $\mathrm{pH}$, Electrical Conductivity (EC), Total Dissolved Salts (TDS), $\mathrm{HCO}_{3}$, $\mathrm{NO}_{3}, \mathrm{SO}_{4}, \mathrm{PO}_{4}, \mathrm{Na}, \mathrm{K}, \mathrm{Ca}, \mathrm{Mg}, \mathrm{Fe}, \mathrm{F}$ and $\mathrm{Pb}$ have been analyzed. The results showed that values of the tested parameters for $\mathrm{EC}, \mathrm{TDS}, \mathrm{HCO}_{3}, \mathrm{SO}_{4}$ and $\mathrm{Na}$ near the sugar mill were very high, which indicate the descent of standard norms of quality and protection procedures for the groundwater around this area. Srinivasamoorthy et al. (2011) found that the water is neutral to alkaline in nature with $\mathrm{pH}$ ranging from 6.6-8.6 with an average of 8.0. Higher electrical conductivity was observed during post-monsoon season. The abundance of major ions in the groundwater was in the order of $\mathrm{Na}>\mathrm{Ca}>\mathrm{Mg}>\mathrm{K}$ $=\mathrm{Cl}>\mathrm{HCO}_{3}>\mathrm{SO}_{4}>\mathrm{NO}_{3}$. Jameel and Sirajudeen (2011) evaluated the current status of physicochemical contaminants and their sources in groundwater.

Misra and Mishra (2007) established the electrical conductivity of 50 samples each from dug wells, hand pumps and tube wells was analyzed for the study of salinity levels in shallow, intermediate and deep aquifers. Out of 50, 20 samples of each were also analyzed for other chemical constituents such as $\mathrm{Na}^{+}$, $\mathrm{K}^{+}, \mathrm{Cl}^{-}, \mathrm{F}^{-}$and TDS. The analyses show drastic changes in the salinity levels of shallow, intermediate and deep aquifers. Moreover, there is an indication that the salinity and concentration of the above chemical constituents also escalate with time in each aquifer. The chemical constituents such as $\mathrm{Na}^{+}, \mathrm{K}^{+}, \mathrm{Cl}^{-}, \mathrm{F}^{-}$and TDS range from $51-165,1-14,224$ to $1459,0-1.5$ and $750-$ $2650 \mathrm{mg} \mathrm{L}^{-1}$, respectively. Over a 3 year period, the salinity levels have sharply increased and the average $\mathrm{F}$ level has increased by $0.1-0.3 \mathrm{mg} \mathrm{L}^{-1}$. An attempt has been made here to discuss the factors causing the variation and escalation of chemical constituents and salinity in the water of the three aquifers.

Several studies have reported that the growth and survival of faecal indicator bacteria are sensitive to environmental factors, such as water temperature (Berry et al., 1991), sunlight (Burkhardt et al., 2000) and rainfall (Kistemann et al., 2002). Therefore, a more reliable indicator of water pollution than faecal bacterial enumeration needs to be developed. The rapid and simple enumeration of faecal bacteria, e.g., faecal coliforms and faecal streptococci, is beneficial in faecal pollution monitoring in geographically large areas and thus several water quality guidelines based on bacterial indicator densities have been established. However, the use of these indicators is controversial, especially in tropical regions characterized by high temperatures and frequent rainstorms that facilitate erosion of soils.

Isobe et al. (2004) mentioned that a reliable assessment of microbial indicators of faecal pollution (total coliforms, E. coli and faecal streptococcus) is critical in tropical environments. Sladecek (1973) gave various examples of the direct relationship between BOD and the benthic invertebrate community. The author allocated a BOD of $2.5 \mathrm{mg} \mathrm{L}^{-1}$, to the lower range of oligosaprobic status, while the $\beta$ mesosaprobic status was characterised by BOD values of about $5.0 \mathrm{mg} \mathrm{L}^{-1}$. Our results showed that the BOD values were laied between 2.5 and $3.5 \mathrm{mg} \mathrm{L}^{-1}$. The abiotic screening criteria are either factors that affect the stream biota directly (P levels for diatoms; BOD, hydromorphology for invertebrates), or indirect, integrative indicators of various human influences (electrical conductivity, land use).

Bacteriological contamination from faecal pollution by anthropogenic sources is considered to be a crucial problem throughout the Danube River basin imposing a threat to all kinds of water uses (Kirschner et al., 2009). Thus, detailed knowledge on the extent and origin of microbial faecal pollution is crucial for watershed management activities in order to maintain safe water use according to the quality targets. Here, our investigations suggested that the Danube surface water quality was highly contaminated in 2010 more than in 2005 due to the sewage effluents.

Escherichia coli and intestinal enterococci are used worldwide as indicators for the assessment of faecal pollution in the aquatic environment. In fresh water, $E$. 
Am. J. Environ. Sci., 8 (3): 202-211, 2012

coli was shown to be a consistent predictor of gastrointestinal illness (Wade et al., 2003).

The use of total and faecal coliforms as indicators of faecal pollution in surface waters in international regulations has been abandoned in recent years because of the discovery that certain species belonging to this group are not of faecal origin (Gauthier and Archibald, 2001).

Attempts to comprehensively monitoring of bacteriological quality in large, international rivers have been tackled by a number of organizations in Europe. For the water of River Danube, the only large-scale bacteriological investigation published to date deals with the changes of bacterial community composition along the whole river was done by Winter et al. (2007).

The bacterial community composition of Danube River in study (Winter et al., 2007) was determined by denaturing gradient gel electrophoresis analysis of PCR-amplified portions of the bacterial 16S rRNA gene from a total of 98 stations on the Danube River (73 stations) and its major tributaries (25 stations), covering a distance of $2851 \mathrm{~km}$.

Shifts in the bacterial community composition were related to changes in environmental conditions found by comparison with physicochemical parameters (e.g., temperature and concentration of nutrients) and the concentration of Chl-a. Apparent bacterial richness in the Danube varied between 18 and 32 bands and correlated positively with the concentration of $\mathrm{P}_{-} \mathrm{PO}_{4}(\mathrm{r}$ $=0.56)$ and negatively with Chl-a $(\mathrm{r}=-0.52)$. Between the cities of Budapest and Belgrade, apparent bacterial richness was significantly lower compared to that of other regions of the river and Chl-a showed a pronounced peak.

The COD data in Fig. 8 are presented for comparative reasons. It can be depicted that the largest portions of wastewater directly entering the Danube However, from the observed microbiological pollution pattern in this study it can be assumed that a large portion also comes from sewage effluent.

Available information on nutrient input along the Danube shows that approximately $65 \%$ of all $\mathrm{N}$ and $43 \%$ of all $\mathrm{P}$ are entering the Danube from non-point sources (Zessner and Gils, 2002). For P compounds, only a significant negative correlation with $\mathrm{O}-\mathrm{PO}_{4}{ }^{3-}$ was observed for the surface water of Danube River in Budapest region. In contrast, significant positive correlations for all faecal indicators were found with bacterial production for the Danube River in Budapest region, while a positive correlation with Chl-a. The input of untreated sewage into the Danube River obviously leads to a concomitant increase in faecal indicators and nutrients enhancing the growthof autotrophic algae.
Inorganic nutrients are depleted by massive algal growth which in turn enhances secondary production like bacteria taking up exuded dissolved organic matter and zooplankton feeding on both phytoplankton and bacterioplankton.

Globally, health problems have been associated with staphylococcal and faecal streptococcal counts, as well as faecal coliforms (Seyfried et al., 1985). Wade et al. (2003) conducted for fresh water, only five observational studies were included in relation to concentrations of $E$ coli. The authors deemed that $E$. coli was the most adequate predictor of gastroenteritis. Due to this nutrient depletion, faecal indicators were not or even negatively correlated with inorganic nutrients, as it was the case for $\mathrm{O}-\mathrm{PO}_{4}{ }^{3-}$.

Although, faecal indicators were highly significantly correlated with bacterial production. The highest Chl-a and organic $\mathrm{N}$ levels were only little faecal polluted indicating that other sources than municipal wastewater, most probably diffuse nutrient entered the Danube River.

Our obsevations are confimed by Gupta et al. (2012) who indicated the cellulase activity of the organisms, by measuring the diameter of clear zone around the colony and hydrolytic value on cellulose Congo Red agar media. Cheshmedjiev et al. (2010) mentioned that the assessment of water body for rivers is difficult to be summarized statistically because of the extremely large differences in size, both in geographic relation and in relation with relative water quantities. Concentrations of $\mathrm{Cd}, \mathrm{Cu}, \mathrm{Pb}$ and $\mathrm{Zn}$ in river water were found to be highest in close proximity to locations of $\mathrm{Cu}$ and $\mathrm{Pb}$ $\mathrm{Zn}$ mining regions in the Maritsa catchment. Downstream dispersal of solute metals in these catchments and into the River Danube, was found to be limited by physical dilution and a well-buffered $\mathrm{pH}$ environment (Bird et al., 2010).

\section{CONCLUSION}

The effects of climate change, pollution, population increase and with large numbers of new chemicals entering the river system, continuous monitoring regime for their detection will become increasingly important with respect to ecological impacts they produce. Much effort has to be directed towards the detection of such pollutants in river.

The frequency of bioindicators in the river is significantly influenced by the flow condition, temperature and transparency of the water, habitat conditions and variations as well as the chemical status of the water environment. Chemical parameters as well as bioindicators adapt and change dynamically in a close interaction with its connected environment. 
Results indicated that the improvement of water quality of the investigated locations of Danube River in Budapest is mainly depending on the many ecological factors and the quality and quantity of the available impurities carried out by the river from the source. Much effort has to be directed towards the detection of such pollutants in rivers. Thus the challenges to continuous physical, chemical, biological and bacteriological monitoring will be immense. Finally the importance of integration of physical, chemical, biological and bacteriological monitoring has to be emphasized.

\section{REFERENCES}

Ahmad, Z. and A. Qadir, 2011. Source evaluation of physicochemically contaminated groundwater of Dera Ismail Khan area, Pakistan. Environ. Monit. Assess., 175: 9-21. DOI: 10.1007/s10661-0101489-1

Berry, C., B.J. Lloyd and J.S. Colbourne, 1991. Effect of heat shock on recovery of Escherichia coli from drinking water. Water Sci. Technol., 24: 85-88.

Bird, G., P.A. Brewer, M.G. Macklin, M. Nikolova and T. Kotsev et al., 2010. Dispersal of contaminant metals in the mining-affected danube and maritsa drainage Basins, Bulgaria, Eastern Europe. Water Air Soil Pollut., 206: 105-127. DOI: 10.1007/s11270-009-0090-0

Birk, S. and D. Hering 2009. A new procedure for comparing class boundaries of biological assessment methods: A case study from the Danube Basin. Ecol. Indicators, 9: 528-539. DOI: 10.1016/j.ecolind.2008.07.006

Burkhardt, W., K.R. Calci, W.D. Watkins, S.R. Rippey and S.J. Chirtel, 2000. Inactivation of indicator microorganisms in estuarine waters. Water Res., 34: 2207-2214. DOI: 10.1016/S00431354(99)00399-1

Chen, K.Y. and S.W. Kueh, 1976. Distribution of heterotrophic bacteria related to some environmental factors in Tolo harbour. Int. J. Ecol. Environ. Sci., 1: 47-58.

Cheshmedjiev, S., R. Mladenov, D. Belkinova, G. Gecheva and I. Dimitrova-Dyulgerova et al., 2010. Development of classification system and biological reference conditions for bulgarian rivers and lakes according to the water framework directive. Biotechnol. Biotechnol. Equipment, 24: 155-163.
Gauthier, F. and F. Archibald, 2001. The ecology of "fecal indicator" bacteria commonly found in pulp and paper mill water systems. Wat. Res., 35: 22072218. PMID: 11358300

Gupta, P., K. Samant and A. Sahu, 2012. Isolation of cellulose-degrading bacteria and determination of their cellulolytic potential. Int. J. Microbiol., 2012: 5-5. DOI: $10.1155 / 2012 / 578925$

Hendricks, C.W., J.D. Doyle and B. Hugley, 1995. A new solid medium for enumerating celluloseutilizing bacteria in soil. Applied Environ. Microbiol., 61: 2016-2019.

Isobe, K.O., M. Tarao, N. H. Chiem, L.Y. Minh and H. Takada, 2004. Effect of environmental factors on the relationship between concentrations of coprostanol and fecal indicator bacteria in tropical (Mekong delta) and temperate (Tokyo) freshwaters. Applied Environ. Microbiol., 70: 814-821. DOI: 10.1128/AEM.70.2.814-821.2004

Jameel, A.A. and J. Sirajudeen, 2011. Risk Assessment of physico-chemical contaminants in groundwater of Pettavaithalai Area, Tiruchirappalli, TamilnaduIndia. Environ. Monit. Assess., 123: 299-312. DOI: 10.1007/s10661-006-9198-5

Jeon, J., J.H. Kim, B.C. Lee and S.D. Kim, 2008. Development of a new biomonitoring method to detect the abnormal activity of Daphnia magna using automated Grid Counter device. Sci. Total Environ., 389: 545-556. PMID: 17961634

Khadse, G.K., M. Kalita, S.N. Pimpalkar, P.K. Labhsetwar, 2011. Drinking water quality monitoring and surveillance for safe water supply in Gangtok, India. Environ. Monit. Assess., 178: 401-414. DOI: 10.1007/s10661-010-1699-6

Kirschner, A.K.T., G.G. Kavka, B. Velimirov, R.L. Mach and R. Sommer et al., 2009. Microbiological water quality along the Danube River: Integrating data from two whole-river surveys and a transnational monitoring network. Water Res., 43: 3673-3684. DOI: 10.1016/j.watres.2009.05.034

Kistemann, T., T. Claßen, C. Koch, F. Dangendorf and R. Fischeder et al., 2002. Microbial load of drinking water reservoir tributaries during extreme rainfall and runoff. Applied Environ. Microbiol., 68: 2188-2197. DOI: 10.1128/AEM.68.5.21882197.2002

Misra, A.K. and A. Mishra, 2007. Escalation of salinity levels in the quaternary aquifers of the Ganga alluvial plain, India. Environ. Geol., 53: 47-56. DOI: $10.1007 / \mathrm{s} 00254-006-0617-2$ 
Seyfried, P.L., R.S. Tobin, N.E. Brown and P.F. Ness, 1985. A prospective study of swimming-related illness. II. Morbidity and the microbiological quality of water. Am. J. Public Health, 75: 10711075. PMID: 4025657

Sladecek, V., 1973. System of Water Quality from the Biological Point of View. 1st Edn., Schweizerbart, Stuttgart, ISBN: 3510470052, pp: 218.

Srinivasamoorthy, K., C. Nanthakumar, M. Vasanthavigar, K. Vijayaraghavan and R. Rajivgandhi et al., 2011. Groundwater quality assessment from a hard rock terrain, Salem district of Tamilnadu, India, Arab. J. Geosci., 4: 91-102. DOI 10.1007/s12517-009-0076-7
Wade, T.J., N. Pai, J.N. Eisenberg, J.M. Colford Jr., 2003. Do U.S. environmental protection agency water quality guidelines for recreational waters prevent gastrointestinal illness? A systematic review and meta-analysis. Environ. Health Perspect., 111: 1102-1109. PMID: 12826481

Winter, C., T. Hein, G. Kavka, R.L. Mach and A.H. Farnleitner, 2007. Longitudinal changes in the bacterial community composition of the Danube River: A whole-river approach. Applied Environ. Microbiol. 73: 421-431.

DOI: 10.1128/AEM.01849-06

Zessner, M. and J.V. Gils, 2002. Nutrient fluxes from the danube basin to the black sea. Water Sci. Technol., 46: 9-17. PMID: 12420961 